\title{
НАЦІОНАЛЬНА ЕКОНОМІКА
}

\author{
УДК 331.523(477):305 \\ DOI: https://doi.org/10.32782/2415-8801/2021-1.4
}

Верховод I.C.

кандидат економічних наук, дочент, доцент кафедри економіки та готельно-ресторанного бізнесу, Мелітопольський державний педагогічний університет імені Богдана Хмельницького

Леушина О.A. кандидат економічних наук, доиент, доцент кафедри економіки та готельно-ресторанного бізнесу, Мелітопольський державний педагогічний університет імені Богдана Хмельницького

\section{ГЕНДЕРНИЙ СКЛАДНИК РОЗВИТКУ СИСТЕМИ СОЩАЛЬНОГО ЗАХИСТУ В УКРАЇНI}

\begin{abstract}
У статті аналізуються чинники функціонування системи соціального захисту населення як відкритої, розгалуженої, багаторівневої й багатофункціональної системи, спрямованої у свойй діяльності на підтримання індивідуально-суспільної рівноваги, активізацію соціально-економічного потенціалу й запобігання негативним наслідкам трансформаційних процесів та мінімізацію соціальних ризиків у суспільстві шляхом законодавчого, економічного, організаційного, управлінського та освітнього забезиечення гендерної рівності. Обгрунтовано використання для соціально-економічного аналізу системи соціального захисту низки категорій, в яких відображено сутність взаємовпливу економічної, соціальної, політичної, організаційної та правової підсистем системи соціального захисту населення та їхню роль у розвитку сталих суспільних відносин. На матеріалах законодавчих, правничих та іниих галузевих джерелах досліджено засади інтегрування тендерного підходу в державну політику Украӥни на міждержсавному, національному і місцевому рівнях та дано оцінку дісвості державних та галузевих заходів щцодо периочергової імплементації Директиви 79/7/СЕС про поступове запровадження принципу рівного ставлення до чоловіків та жінок у сфері соціального забезпечення. Виявлено основні проблемні аспекти впровадження механізмів соціального забезпечення, політики зайнятості, охорони здоров'я, цио чинять суттєвий вплив на стан тендерної рівності в Украӥні.

Ключові слова: соціальний захист, тендерна рівність, тендерний підхід, система сочіального захисту, тендерна соціальна політика.
\end{abstract}

\section{THE GENDER COMPONENT OF THE DEVELOPMENT OF THE SYSTEM OF THE SOCIAL PROTECTION IN UKRAINE}

\author{
Verkhovod Iryna, Leushyna Olena \\ Bohdan Khmelnitsky Melitopol State Pedagogical University
}

The factors of the functioning of the system of the social protection of the population have been analyzed in the article as the open, the ramified, the multilevel and the multifunctional system aimed at the maintenance of the individual-social balance in its activity, the activation of the socio-economic potential and the prevention of the negative consequences of the transformational processes and the minimization of the social risks in the society by means of legislative, economic, organizational, managerial and educational support of the gender equality. The use for the social-economic analysis of the system of the social protection of the numbers of the categories has been grounded, where the essence of the interaction of economic, social, political, organizational and legal subsystems of the system of the social protection has been reflected and their role in the development of the sustainable social relations. The principles of the integration of the gender approach into the state policy of Ukraine at the interstate, the national and the local levels have been researched on the basis of legislative, legal and other branch sources and the marks of the effectiveness of the state and the branch measures has been given as for the priority implementation of Directive 79/7/EEC about gradually implementation of the principle of the equal attitude for the men and the women in the sphere of the social providing, the main problematic aspects of the implementation of the mechanisms of the social providing, the policy of the employment, health care have been revealed, which have the significant impact on the state of the gender equality in Ukraine. The ways of the increase of the level of the compliance of the principle of the gender have been determined equality in terms of the improvement of the normative-legal base, the accounting of the gender components in the programs of the economic and the social development, the improvement of the mechanism of the realization of the gender-legal expertise, the improvement of the realization of the mechanisms of the right to the 
protection from the discrimination on the basis of sex, making the gender component to the programs of the social reforms with the involvement of the public authorities, the local self-governments and the public organizations and the associations, the activities are aimed at the providing of the equal rights and the opportunities of the women and the men.

Keywords: social protection, gender equality, gender approach, system of social protection, gender social policy.

Постановка проблеми. Забезпечення рівних прав і можливостей жінок і чоловіків у системі соціального захисту нашої країни є одним із нагальних завдань ефективної трансформації суспільної системи цінностей для забезпечення розвитку демократії та подолання всебічної залежності людини від держави. Одним 3 основоположних принципів Статуту ООН, прийнятого в 1945 р., є «рівноправність чоловіків і жінок». Принцип гендерної рівності був визнаний у Загальній декларації прав людини у 1948 р., що стала відправною точкою для подальшого зміцнення міжнародних зобов'язань, що стосуються прав жінок. У найбільш повному обсязі ці права були закріплені в Конвенції ООН про ліквідацію всіх форм дискримінації щодо жінок 1979 р. Досягнення рівності між жінками та чоловіками є однією з головних цілей і невід'ємною частиною національного та міжнародного порядку денного у сфері соціально-економічного розвитку. Принцип гендерної рівності втілює здійснення прав людини на гарантовані рівні права, обов'язки і можливості. Цей принцип закріплений у численних міжнародних договорах, національних конституціях і законодавчих актах держав усього світу, у тому числі й України. У цьому вимірі соціальна захищеність як специфічний параметр суспільного устрою визначається, насамперед, рівноправністю всіх суб'єктів суспільного життя у всіх суспільних сферах, зокрема в системі соціальнотрудових відносин. У контексті сьогодення зазначимо також рекомендації Всесвітньої організації охорони здоров'я враховувати гендерну проблематику під час здійснення протиепідемічних заходів щодо COVID-19, щоб у процесі реалізації стратегій і заходів у сфері охорони здоров'я, спрямованих на стримування епідемії, бралися до уваги гендерні аспекти та їх взаємозв'язок 3 іншими проявами нерівності.

Отже, актуальність звернення до цієї проблеми визначається тим, що існує як нерівність у розподілі економічних ресурсів між чоловіками та жінками через гендерний поділ праці і реальний внесок у матеріальне забезпечення добробуту сімей, домогосподарств, який підтримується за допомогою конструювання відповідних соціальних чоловічих i жіночих ролей, так i недостатньо системно опрацьованим є обгрунтування перспектив розширення соціально-економічних можливостей представників обох статей у професійній діяльності, доступі до влади, сімейній ролі, репродуктивній поведінці тощо.

Аналіз останніх досліджень і публікацій. Сьогоденна гендерна політика в Україні грунтується на низці основних міжнародних нормативно-правових актів, ратифікованих Україною, та регулюється національними нормативно-правовими актами щодо рівності між жінками й чоловіками, зокрема Конвенцією ООН «Про ліквідацію всіх форм дискримінації щодо жінок» та Законом України «Про забезпечення рівних прав та можливостей жінок і чоловіків» [6], скеровується й координується на даному етапі Державною соціальною програмою забезпечення рівних прав та можливостей жінок і чоловіків на період до 2021 р., затвердженою
Постановою Кабінету Міністрів України від 11 квітня 2018 р. № 273 [2], метою якої є вдосконалення механізму забезпечення рівних прав та можливостей жінок і чоловіків у всіх сферах життя суспільства та впровадження європейських стандартів рівності.

Гендерні аспекти державної політики сьогодні активно опрацьовані такими науковцями, як Т. Мельник, Н. Світайло [8], Л. Пірог, Н. Грицяк та ін. Питання гендерного інтегрування - впровадження гендерного підходу у всі сфери політики та засади гендерної політики в системі державного управління - грунтовно досліджують М. Білинська, Л. Воронько, Л. Гонюкова, В. Дерега, С. Свченко [3], О. Москаленко, О. Остапчук [3], О. Приходько та ін. Разом із тим гендерні дослідження проблеми соціального захисту й соціальної захищеності Е. Лібанової, Л. Пірог, М. Руженського, Л. Суслової, О. Туленкова [9], матеріали соціологічних досліджень, громадських практик упровадження недискримінаційних норм, зокрема Директиви NN 2000/43/СС від 29 червня 2000 р. «Щодо імплементації принципу рівноправності осіб незалежно від расової або етнічної приналежності», засвідчують потребу більш детального аналізу іiі чинників та подальшого експертного супроводу.

Постановка завдання. Метою статті $\epsilon$ аналіз законодавчого, правового та соціально-економічного супроводу розвитку гендерних аспектів системи соціального захисту в Україні та обгрунтування перспектив розширення соціально-економічних можливостей забезпечення рівних прав i можливостей жінок та чоловіків у системі соціального захисту нашої країни.

Виклад основного матеріалу дослідження. Українське суспільство на сучасному етапі набуває змін як у системі політичних перетворень, нових технологій, способів організації економіки, так і стосовно усталених уявлень щодо ролевої участі жінки й чоловіка в сучасних суспільних трансформаціях. Україна зобов'язується поступово «наблизити своє законодавство до законодавства ЄС у галузі зайнятості, соціальної політики та рівних можливостей» [10, с. 18]. Свідченням визнання державою важливості гендерних питань було прийняття Закону України «Про забезпечення рівних прав та можливостей жінок і чоловіків» у 2005 р., на сучасному етапі - прийняття Державної програми гендерного розвитку (2018р.). Уперше за майже 40 років із моменту ратифікації Україною Конвенції про ліквідацію всіх форм дискримінації щодо жінок (КЛДЖ) прийнято «Національний план дій із виконання рекомендацій, викладених у заключних зауваженнях Комітету ООН з ліквідації дискримінації щодо жінок» на період до 2021 р. Реалізація заходів Плану сприятиме подоланню найбільш гострих проявів дискримінації щодо жінок і дівчат, зниженню рівня гендерно зумовленого насильства, розширенню економічних можливостей жінок, забезпеченню рівного доступу до правосуддя, участі у прийнятті рішень у політичному та суспільному житті тощо [4].

Однак, як зазначають С. Свченко та О. Остапчук, юридична рівність не завжди зумовлює рівність фак- 
тичну і рівність економічну [3, с. 14]. Тому, визначаючи систему соціального захисту населення як відкриту, розгалужену, багаторівневу й багатофункціональну систему, дія якої спрямована на підтримання індивідуально-суспільної рівноваги, активізацію соціальноекономічного потенціалу й запобігання негативним наслідкам трансформаційних процесів та мінімізацію соціальних ризиків у суспільстві шляхом законодавчого, економічного, організаційного, управлінського та освітнього забезпечення, яке базується на двосторонньому зв'язку із соціумом, окремими соціальними верствами населення [9], зазначимо, що гендерна критика соціальної політики в багатьох міждисциплінарних дослідженнях спрямовується переважно «на виявлення тих механізмів соціального забезпечення, політики зайнятості, охорони здоров'я, які впливають на погіршення становища жінок, посилюють або відтворюють ґендерну нерівність» [8]. Саме тому постає нагальне завдання вивчення засад інтегрування гендерного підходу в державну політику України як на національному, так і на місцевому рівні, а також визначення ролі дієвості заходів у соціальній політиці на матеріалах законодавчих, правничих та інших галузевих компонент соціальної захищеності населення.

Теоретичним підгрунтям упровадження гендерного підходу слугує низка категорій, що використовуються для аналізу структури і змістовних компонент процесу інтегрування гендерного підходу в соціальній політиці сучасної України. Насамперед це категорія соціальної захищеності населення, що визначається як результат дії складників системи соціального захисту населення як економічної, соціальної, політичної, організаційної та правової підсистем суспільних відносин. Ці підсистеми тісно між собою взаємопов'язані, і тільки їх взаємодія постає у вигляді інтегрованого утворення соціальної захищеності населення [7]. Таким чином, гендерний підхід виконує роль діагностичного інструментарію подолання неефективного розподілу соціальних та економічних ресурсів між статями, визначає ситуацію з позиції критичного осмислення, відкриває інверсійність соціальної політики стосовно чоловічої й жіночої суспільних страт для можливої деконструкції чинної ієрархії статей на всіх рівнях усіма суб'єктами політичної діяльності в процесі реорганізації, реформування й оновлення, зміни і розвитку суспільства, визначення напрямів і оцінки політичних перетворень. Як складова частина соціальної справедливості гендерний паритет відображає принцип реального визнання рівноваги в суспільному житті між статями у праві вибору, використанні можливостей, гендерній самоідентифікації й особистій самореалізації, а рівність прав означає наділення однаковими правами де-юре осіб жіночої та чоловічої статей у всіх сферах життя та забезпечення де-юре рівних умов утілення у різних сферах життєдіяльності. Часто використовуване поняття рівності можливостей змістово означає наявність системи засобів, підкріплених правовими гарантіями досягнення де-факто рівних умов щодо доступу, розподілу, використання політичних, економічних, соціальних та культурних цінностей, тобто вказує не лише на правові, а й на соціально-економічні та соціально-культурні аспекти проблеми [3, с. 53]. Отже, соціальна практика сьогодні підтверджує потребу переходу державної політики від забезпечення пев- них функцій - освіти, охорони здоров’я, культури, житлово-комунального господарства та соціального захисту - до інтегрованих форм політики соціального розвитку [10].

Як можемо констатувати з огляду чинних документів, згідно з Угодою про асоціацію між Україною та СС, в Україні відбувається активний процес реформування законодавства у соціальній сфері. Упродовж останніх років робота спрямовується на проведення імплементації директив ЄС у соціальній сфері та виконання положень Підрозділу 21 «Співробітництво у галузі зайнятості, соціальної політики та рівних можливостей» Розділу V Угоди про асоціацію. Урядом ратифіковано низку документів і нормативно-правових актів, серед яких відзначимо Конвенцію Міжнародної організації праці про мінімальні норми соціального забезпечення № 102 (березень 2016 р.), Свропейський кодекс соціального забезпечення (листопад 2016 р.). У рамках проєкту 2017 р. «Практики роботи Міністерства соціальної політики України із забезпечення рівності жінок і чоловіків на ринку праці в контексті імплементації відповідних директив ЄС» представлено дослідження «Гендерна дискримінація у доступі до праці й послуг: оцінка стану впровадження Україною антидискримінаційних директив Ради ЄС» $[1$, с. 6].

Рекомендації за результатами проєкту були також представлені на міжнародній конференції «Уряд і бізнес: чи є перспективи впровадженню недискримінаційних норм на українському ринку праці?» за участю представників Міністерства соціальної політики України, Державної служби зайнятості, Державної служби України з питань праці, науковців НДІ праці і зайнятості населення, міжнародних експертів Ради Свропи та країн Східного партнерства (Молдова, Грузія, Вірменія), фахівців Центру проблем імплементації європейського соціального права.

За підсумками конференції було прийнято резолюцію, в якій учасники надали пропозиції щодо посилення недискримінаційної політики на українському ринку праці. Було дано оцінку результатам упровадження в Україні шести «недискримінаційних» директив Ради $\mathrm{CC}$, які стосуються рівних можливостей для українських громадян незалежно від статі поєднувати сімейне життя 3 професійним, будувати систему соціального забезпечення з урахуванням принципу рівності, запроваджувати принцип гендерно рівного ставлення в доступі до товарів та послуг, а також у сфері 3МІ, рекламі та освіті.

У 2018 р. ГО «Бюро соціальних та політичних розробок» у співпраці з партнерами в рамках виконання проєкту «Практики роботи Міністерства соціальної політики України щодо посилення експертної роботи 3 імплементації «антидискримінаційних» директив Ради ЄС» проведено аналіз стану імплементації, відповідності нормам вітчизняного законодавства та дієвості механізмів регулювання рівності та недискримінації у доступі до праці, послуг та соціального забезпечення щодо директив, визначених до першочергової імплементації в згідно з Угодою про асоціацію між Україною та Європейським Союзом (Директиви № 92/85/СЕС про вжиття заходів з поліпшення безпеки та охорони здоров'я на виробництві вагітних працівниць, працівниць, які нещодавно народили або годують (десята індивідуальна Директива у значенні статті 16 (1) Дирек- 
тиви 89/391/СЕС); Директиви № 79/7/СЕС від 19 грудня 1978 р. «Про поступову імплементацію принципу рівності чоловіків і жінок у сфері соціального забезпечення»; Директиви Ради 2004/113/СС від 13 грудня 2004 р. про імплементацію принципів рівності чоловіків і жінок у доступі до товарів і надання послуг) [10].

Звіт про виконання Угоди про асоціацію між Україною та Європейським Союзом у 2018 р. засвідчив досягнення значного прогресу в соціальній сфері та трудових відносинах, а сьогодні Україна продовжує роботу з упровадження принципів гендерної рівності (затверджено Державну соціальну програму забезпечення рівних прав та можливостей жінок і чоловіків на період до 2021 р. і Національний план дій із виконання заключних зауважень Комітету $\mathrm{OOH}$ із ліквідації дискримінації щодо жінок).

Разом із тим результати Національного опитування щодо рівності чоловіків та жінок [5] констатують значний суспільний запит на тематику гендерної рівності (77\% українців стверджують, що рівність між чоловіками та жінками важлива для них. Більше ніж дві третини українців бачать, що нині в політичному житті країни домінують чоловіки, але лише 36\% уважають, що так має бути), засвідчують актуальність звернення до цієї проблеми перспектив розширення соціальних можливостей обох статей у професійній діяльності, доступі до влади, сімейній ролі, репродуктивній поведінці тощо. Нижче наводимо аналіз стану імплементації «Директиви 79/7/СЕС про поступове запровадження принципу рівного ставлення до чоловіків та жінок у сфері соціального забезпечення», що охоплює державні системи обов'язкового соціального забезпечення, які передбачають захист від таких ризиків, як хвороба, інвалідність, старість, безробіття, нещасні випадки на виробництві та професійні захворювання.

Частково положення Директиви стосуються і соціальних допомог, якщо вони спрямовані на доповнення чи заміну названих вище систем соціального забезпечення. Загалом, згідно з Директивою 79/7/СЕС, під принципом рівного ставлення розуміється відсутність будь-якої прямої чи непрямої дискримінації за ознакою статі, зокрема щодо шлюбного або сімейного статусу щодо:

а) сфери застосування режимів соціального забезпечення й умов доступу до них;

б) зобов'язань здійснювати внески й обчислення їх розміру;

в) визначення розміру соціальних виплат, умов, які регулюють строки виплат і збереження права на їх отримання.

При цьому у ст. 4 Директиви наголошено, що принцип рівності у ставленні існує без шкоди для положень про захист матерів, тобто, встановлення додаткових гарантій у сфері соціального забезпечення для жінок у зв'язку з материнством може бути виправданим та не вважатиметься дискримінацією.

Так, в Україні цей виняток стосується соціальних допомог для жінок у зв'язку з вагітністю та пологами. Регламентуючи принцип рівного ставлення до чоловіків та жінок, Директива 79/7/ЄЕС визначає можливість державам-членам за іiї імплементації зберегти виключення зі сфери іiі дії, що стосуються обмеженого кола питань, зокрема:

а) визначення пенсійного віку для звернення з проханням отримувати пенсії при виході на пенсію й осо- бам похилого віку, а також для пов'язаних із цим інших грошових виплат;

б) переваги щодо програм задоволення прохання про виплату пенсій особам похилого віку, які виховували дітей; здобуття права на грошову допомогу під час перебування у декретній відпустці;

в) задоволення прохання про виплату грошової допомоги непрацездатним особам або людям похилого віку на основі прав, похідних від дружини;

г) задоволення прохання про збільшення грошової допомоги дружині, яка перебуває на утриманні, за довготривалої інвалідності, у разі нещасних випадків на виробництві, професійних хвороб і для осіб похилого віку.

У цілому положення Директиви 79/7/ЄЕС, що визначають іï цілі, завдання та сферу дії, враховано в національному законодавстві. Передбачено загальні норми, що регламентують рівність чоловіків та жінок у сфері соціального забезпечення: Конституція України, Закон України «Про забезпечення рівних прав та можливостей жінок і чоловіків» [6]. Водночас у спеціальних законодавчих актах, що регламентують окремі види та форми соціального забезпечення, зокрема Основах законодавства України про загальнообов'язкове державне соціальне страхування, законах України «Про загальнообов'язкове державне соціальне страхування», «Про загальнообов'язкове державне пенсійне страхування», «Про загальнообов'язкове державне соціальне страхування на випадок безробіття», «Про соціальні послуги» тощо, принцип рівності загалом, та гендерної рівності зокрема не закріплено. Це, на нашу думку, є одним з основних недоліків поточного стану імплементації Директиви 79/7/СЕС. Законодавство України передбачає створення рівних умов для жінок і чоловіків щодо отримання соціальних та пенсійних виплат. Громадяни незалежно від статі мають право на соціальний захист, що включає право на забезпечення їх у разі повної, часткової або тимчасової втрати працездатності, втрати годувальника, безробіття 3 незалежних від них обставин, а також у старості та в інших випадках, передбачених законом (ст. 46 Основного Закону). Загальнообов'язкове державне пенсійне страхування здійснюється за принципом рівноправності застрахованих осіб щодо отримання пенсійних виплат.

Особи мають право на призначення пенсії за віком після досягнення віку 60 років на відміну від попереднього законодавства, що передбачало розрив у п’ять років між чоловіками та жінками щодо пенсійного віку. При цьому сьогодні законодавство передбачає поступове (до 2021 р.) підвищення пенсійного віку жінкам із 55 до 60 років.

Національне законодавство визначає та гарантує соціальний захист (у вигляді соціального страхування) для всіх страхових випадків, передбачених ст. 2 Директиви. Зокрема, визначено законодавчо соціальне страхування на випадок безробіття, нещасного випадку, тимчасової непрацездатності, а також старості (пенсійне страхування). Законодавчо гарантується надання соціального страхування усьому працюючому населенню, у тому числі самозайнятим особам, які є застрахованими особами. Проте існують окремі прогалини у чинному соціально-забезпечувальному законодавстві, які потребують удосконалення згідно з вимогами Директиви, у тому числі стосовно регламентації дієвих механізмів захисту особи від дискримінації у сфері соціального забезпечення. 
На основі детального порівняння положень Директиви 79/7/СЕС та національного соціально-забезпечувального законодавства (порівняльна таблиця аналізу відповідності національного законодавства нормам Директиви 79/7/€EC - на www.bureau.in.ua) можна визначити основні проблемні аспекти щодо стану іiі імплементації в Україні:

а) відсутність закріплення принципу гендерної рівності у спеціальному законодавстві щодо соціального забезпечення. Принцип рівності, зокрема рівності за ознакою статі, закріплено лише в загальних нормах: Конституції України, законах України «Про забезпечення рівних прав та можливостей жінок і чоловіків», «Про засади запобігання та протидії дискримінації в Україні». Водночас спеціальні законодавчі акти окремо не регламентують принцип гендерної рівності щодо надання окремих видів соціального забезпечення, що потребує виправлення 3 метою повного врахування положень Директиви;

б) розбіжності у застосуванні термінів щодо визначення соціальних ризиків. Національне законодавство регламентує соціальний захист чоловіків та жінок щодо всіх соціальних ризиків, визначених ст. 3 Директиви. При цьому, частково терміни щодо соціальних ризиків, які $\epsilon$ підставою для надання окремих видів соціального забезпечення, відрізняються в Україні. Так, замість такого ризику, як хвороба, законодавство України регламентує тимчасову непрацездатність, що, крім безпосередньо хвороби, включає також період вагітності та пологів. Стосовно такого соціального ризику, як старість, окремо він також у національному законодавстві не визначений. Так, Закон України «Про загальнообов’язкове державне пенсійне страхування» визначає підставами для надання пенсії за віком необхідність наявності таких юридичних фактів, як досягнення пенсійного віку та наявність відповідного страхового стажу. Якщо наявний лише один із указаних юридичних фактів - вік, особа не має права на отримання пенсії. Водночас із досягненням 63 років право на отримання соціальної допомоги набувають особи, які не мають права на пенсію відповідно до Закону України «Про державну соціальну допомогу особам, які не мають права на пенсію, та особам з інвалідністю». Тобто фактично старість як соціальний ризик, відповідно до національного законодавства, передбачає надання соціального забезпечення (оскільки досягнення пенсійного віку - 60 років можна відносити до старості відповідно до класифікації Свропейського регіонального бюро Всесвітньої організації охорони здоров'я: старіння (похилий вік) триває у чоловіків 361 до 74 років, у жінок - з 55 до 74 років, із 75 років настає старість (похилий вік)). При цьому в Україні саме старість як підстава для надання соціального забезпечення не отримала закріплення. Інші види соціальних ризиків, визначені ст. 3 Директиви, передбачено й у законодавстві України: інвалідність, безробіття, нещасні випадки на роботі i професійні хвороби (щодо останнього отримав назву «нещасні випадки, пов'язані з виробництвом, та професійні захворювання»). У разі хвороби (тимчасової непрацездатності), нещасних випадків на виробництві та професійних захворювань передбачено матеріальну допомогу та соціальні послуги в рамках загальнообов'язкового державного соціального страхування; при інвалідності та старості - у рамках загальнообов'язкового державного пенсійного страху- вання; щодо безробіття - загальнообов'язкового державного соціального страхування на випадок безробіття.

Додатково в законодавстві України передбачено державну соціальну допомогу особам, які не мають права на пенсію (за відсутності відповідного страхового стажу);

в) наявність дискримінаційних норм за ознакою статі у соціально-забезпечувальному законодавстві.

У цілому національне законодавство передбачає здійснення соціального забезпечення за настання визначених Директивою 79/7/ЄЕС соціальних ризиків незалежно від статі. Так, виплати та соціальні послуги в межах загальнообов'язкового державного соціального страхування, регламентовані відповідним Законом, однаковою мірою надаються чоловікам та жінкам.

Законом України «Про державну допомогу сім'ям iз дітьми» встановлено рівні права та можливості на призначення допомоги сім'ям із дітьми для жінок та чоловіків (окрім соціальної допомоги у зв'язку з вагітністю та пологами, право на яку мають лише жінки). Тобто відповідні положення законодавства відповідають принципу гендерної рівності. Під час визначення розмірів відповідних виплат із соціального страхування до уваги беруться лише тривалість страхового стажу та розмір заробітної плати (доходу). Такий принцип відображено в усіх законодавчих актах щодо загальнообов'язкового державного соціального страхування. Водночас слід відзначити наявність дискримінаційних за гендерною ознакою норм щодо призначення мінімальної пенсії за віком та пенсій 3 інвалідності непрацюючим особам II групи.

Закон України «Про загальнообов'язкове державне пенсійне забезпечення» в окремих випадках надання соціального забезпечення передбачає різні вимоги до страхового стажу для чоловіків та жінок, хоча загалом сьогодні в Україні внаслідок пенсійної реформи страховий стаж, як і пенсійний вік, для призначення пенсійних виплат визначено однаковим для чоловіків та жінок.

Зазначені положення статей 28, 33 Закону «Про загальнообов'язкове державне пенсійне страхування» вважаємо дискримінаційними. Ці норми не відповідають вимогам Директиви 79/7/СЕС та положенням національного законодавства, що гарантують рівність, у тому числі й за ознакою статі, та потребують зміни шляхом установлення однакових вимог до страхового стажу для чоловіків та жінок.

Оскільки ст. 7 Директиви 79/7/СЕС передбачає можливість урахування окремих обставин для визначення різних умов соціального забезпечення чоловіків та жінок, положення національного законодавства щодо дострокового виходу на пенсію в окремих випадках, лише чоловіків або жінок, не порушують принципу рівності ставлення.

Такі положення, що нормативно закріплюють гендерну нерівність, не є обгрунтованими та потребують внесення змін;

г) відсутність механізму протидії непрямій дискримінації у соціально-забезпечувальному законодавстві.

Згідно зі ст. 4 Директиви 79/7/СЕС, принцип рівності у ставленні означає, що не існує ні прямої, ні непрямої дискримінації за ознакою статі, зокрема щодо шлюбного або сімейного статусу. В Україні законодавством у цілому гарантовано рівність від прямої дискримінації. Необхідність забезпечення рівності у ставленні шля- 
хом заборони непрямої дискримінації в національному законодавстві фактично не відображено. Так, лише поняття «непряма дискримінація» закріплено в Законі України «Про засади запобігання та протидії дискримінації в Україні», механізму реальної протидії непрямій дискримінації не визначено. Поняття «непряма дискримінація» взагалі не застосовується у Законі України «Про забезпечення рівних прав і можливостей жінок та чоловіків». При цьому, оскільки існує дискримінаційна практика у сфері праці, часто чоловіки займають більш оплачувані посади, і загалом, наявний розрив у сфері оплати праці, жінки отримують близько 70\% від оплати праці чоловіків, у тому числі внаслідок непрямої дискримінації. Відповідно, це призводить і до непрямої дискримінації у сфері соціального захисту, оскільки, крім страхового стажу, другим ключовим показником для визначення розміру пенсій, інших соціальних виплат у межах загальнообов'язкового державного соціального страхування є розмір заробітної плати (доходу). Тому необхідно на законодавчому рівні визначити механізм протидії непрямій дискримінації за ознакою статі у сфері соціального забезпечення;

г) недосконалість механізму проведення антидискримінаційної та гендерно-правової експертизи нормативно-правових актів.

Законодавство України визначає необхідність проведення антидискримінаційної та гендерно-правової експертизи як проєктів нормативно-правових актів, так і уже чинних нормативно-правових актів. Указані положення сприяють реалізації ст. 5 Директиви 79/7/ СEC, що визначає: «Держави-члени вживають заходів, необхідних для забезпечення того, що будь-які закони, підзаконні акти й адміністративні положення, які не відповідають принципу рівності у ставленні, були скасовані». Відповідно, це сприяє можливості виявлення та усунення норм, що порушують принцип рівності у сфері соціального захисту.

Висновки 3 проведеного дослідження. Основним завданням функціонування відкритої, розгалуженої, багаторівневої й багатофункціональної системи соціального захисту населення є підтримання суспільної рівноваги, активізація соціально-економічного потенціалу всіх соціальних страт, запобігання негативним наслідкам трансформаційних процесів та мінімізація соціальних ризиків у суспільстві шляхом законодавчого, економічного, організаційного та управлінського забезпечення гендерної рівності.

Українська держава послідовно впроваджує основні елементи нормативно-правової бази сталого розвитку на засадах євроінтеграційного руху, сприяючи гендерній рівності й протидіючи дискримінації за ознакою статі, однак на практиці в українському суспільстві констатується значний запит на вдосконалення механізмів дотримання принципів гендерної рівності, що потребує активізації наукового супроводу та координації зусиль.

Аналіз законодавчої бази, матеріалів науководослідницьких джерел, звітів реалізації чинних міжнародних та державних програм соціального захисту засвідчує взаємовплив функціонування економічної, соціальної, політичної, організаційної та правової підсистем системи соціального захисту населення, виявляє певні проблеми та недоліки інтегрування гендерного підходу в державну політику України на міждержавному, національному і місцевому рівнях та дієвості механізмів державних та галузевих заходів у соціальній політиці та потребу їх удосконалення для розвитку сталих суспільних відносин.

Аналіз дієвості державних та галузевих заходів щодо першочергової імплементації Директиви 79/7/ЄЕС про поступове запровадження принципу рівного ставлення до чоловіків та жінок у сфері соціального забезпечення, що охоплює державні системи обов'язкового соціального забезпечення, що передбачають захист від таких ризиків, як хвороба, інвалідність, старість, безробіття, нещасні випадки на виробництві та професійні захворювання на матеріалах законодавчих, правничих та інших галузевих джерел, засвідчує низку невідповідностей, які суттєво обмежують ефективність гендерних програм на практиці.

Проведений аналіз реалізації чинної законодавчої бази та державних програм останніх років дає змогу визначити основні напрями розвитку механізмів підвищення рівня соціального забезпечення, політики зайнятості, охорони здоров'я, що чинять суттєвий вплив на стан гендерної рівності в Україні:

- підвищення рівня дотримання принципу гендерної рівності в аспектах удосконалення нормативноправової бази;

- урахування гендерного компонента в комплексних програмах економічного та соціального розвитку;

- удосконалення механізму проведення гендерноправової експертизи механізмів реалізації права на захист від дискримінації за ознакою статі;

- внесення гендерного складника до стратегій і програм реформ із залученням органів державної влади, місцевого самоврядування та громадських організацій і об’єднань, діяльність яких спрямовується на забезпечення рівних прав та можливостей жінок і чоловіків.

\section{Список використаних джерел:}

1. Аналіз регулювання дотримання рівності та недискримінації у доступі до праці, послуг та соціального забезпечення: оцінка стану впровадження Україною антидискримінаційних директив ЄС : аналітичний звіт за результатами дослідження. Київ, 2019. 49 с.

2. Державна соціальна програма забезпечення рівних прав та можливостей жінок і чоловіків на період до 2021 року : Постанова Кабінету Міністрів України № 273 від 11 квітня 2018 р.

3. Євченко С.В., Остапчук О.Л. Впровадження комплексного гендерного підходу в роботу органів державної виконавчої влади на регіональному рівні : методичні рекомендації. Житомир : ФОП Оржехівський А.О., 2018. 56 с.

4. Звіт про діяльність віцепрем'єрки з питань європейської та євроатлантичної інтеграції Іванни КлимпушЦинцадзе з реалізації політики гендерної рівності за 2017 р. - I півріччя 2019 p. URL: http://eu-ua.org/sites/default/ files/inline/files/zvit_po_genderu_-_19_07_2019.pdf (дата звернення: 11.11.2020).

5. Національне опитування щодо рівності чоловіків та жінок (липень 2018 р.). URL: https://www.kmu.gov.ua/ ua/news/ivanna-klimpush-cincadze-prezentuvala-rezultati-pershogo-nacionalnogo-opituvannya-shchodo-rivnosticholovikiv-ta-zhinok (дата звернення: 14.11.2020). 
6. Про забезпечення рівних прав та можливостей жінок і чоловіків : Закон України від 08.09.2005 № 2866-IV. URL: http//www.president.gov.ua/documents/3308.html (дата звернення: 10.11.2020).

7. Руженський М.M. Соціальна захищеність населення в умовах формування ринкової моделі економіки України : монографія. Київ : ІПК ДСЗУ, 2013. 318 с.

8. Світайло Н., Павленко В., Костенко А. Гендерний портрет українського суспільства. Аналітичне дослідження. Суми : СумДУ, 2009. 81 с.

9. Туленков М.В., Шайгородський Ю.Ж. Політика соціального захисту : монографія. Київ : Центр соціальних комунікацій, 2011. 184 с.

10. Угода про асоціацію між Україною та ЄС: соціально-трудовий вимір. Книга перша: збірник актів законодавства України та acquis communautaire. Львів : Суспільство і довкілля, 2015. 1144 с.

\section{References:}

1. Analiz rehulyuvannya dotrymannya rivnosti ta nedyskryminatsiyi u dostupi do pratsi, posluh ta sotsial'noho zabezpechennya: otsinka stanu vprovadzhennya Ukrayinoyu antydyskryminatsiynykh dyrektyv YES [Analysis of regulation of equality and non-discrimination in access to labor, services and social security: assessment of state of implementation of Ukraine's anti-discrimination directives] (2019). Kyiv. (in Ukrainian)

2. Derzhavna sotsial'na prohrama zabezpechennya rivnykh prav ta mozhlyvostey zhinok i cholovikiv na period do 2021 roku (Postanova Kabinetu Ministriv Ukrayiny № 273 vid 11 kvitnya 2018 r.) [State social program of providing of equal rights and opportunities for women and men for period up to 2021: resolution of the Cabinet of Ministers of Ukraine № 273 of April 11] (2018). (in Ukrainian)

3. Yevchenko, S.V, Ostapchuk, O.L. (2018) Vprovadzhennya kompleksnoho gendernoho pidkhodu $v$ robotu orhaniv derzhavnoyi vykonavchoyi vlady na rehional'nomu rivni: Metodychni rekomendatsiyi [Implementation of complex gender approach in work of state executive bodies at regional level]. Zhytomyr: FOP Orzhekhivsky A.O. (in Ukrainian)

4. Zvit pro diyal'nist' vitsepremyerky z pytan' yevropeys'koyi ta yevroatlantychnoyi intehratsiyi Ivanny Klympush-Tsyntsadze z realizatsiyi polityky gendernoyi rivnosti za 2017r. - I pivrichchya 2019 r. [Report about activities of Vice Prime Minister on questions of European and Euro-Atlantic Integration of Ivanna Klympush-Tsintsadze on implementation of gender equality policy for 2017. - the first half of 2019] (2019). Retrieved from: http://eu-ua.org/sites/ default/files/inline/files/zvit_po_genderu_-_19_07_2019.pdf (accessed 11 November 2020). (in Ukrainian)

5. Natsional'ne opytuvannya shchodo rivnosti cholovikiv ta zhinok (lypen' 2018 r.) [National survey on equality between men and women (July 2018)]. Retrieved from: https:/www.kmu.gov.ua/ua/news/ivanna-klimpush-cincadze-prezentuvala-rezultati-pershogo-nacionalnogo-opituvannya-shchodo-rivnosti-cholovikiv-ta-zhinok (accessed 14 November 2020). (in Ukrainian)

6. Pro zabezpechennya rivnykh prav ta mozhlyvostey zhinok i cholovikiv: Zakon Ukrayiny vid 08.09.2005 r. № 2866- IV [About providing of equal rights and opportunities for women and men: Law of Ukraine of 08.09.2005 № 2866-IV]. Retrieved from http// www. president.gov.ua/documents/3308.html (accessed 10 November 2020). (in Ukrainian)

7. Ruzhenskyi, M.M. Sotsial'na zakhyshchenist' naselennya v umovakh formuvannya rynkovoyi modeli ekonomiky Ukrayiny [Social protection of population in condition of formation of market model of the economy of Ukraine]. Kyiv: IPK DSZU. (in Ukrainian)

8. Svitailo, N. (2009) Hendernyy portret ukrayins'koho suspil'stva. Analitychne doslidzhennya [Gender portrait of Ukrainian society. Analytical research]. Sumy: Vyd-vo SumDu. (in Ukrainian)

9. Tulenkov, M.V. (2011) Polityka sotsial'noho zakhystu [Politics of social protection]. Kyiv: Center for Social Communications. (in Ukrainian)

10. Kozak, Z.Ya. (2015) Uhoda pro asotsiatsiyu mizh Ukrayinoyu ta YES: sotsial'no-trudovyy vymir [Association Agreement between Ukraine and the EU: social and labor dimension]. Lviv: Resource and Analytical Center "Society and Environment". (in Ukrainian)

E-mail: verkhovod-ira@ukr.net 